\title{
ディーゼル発電系統に連系した太陽光発電の 最適容量と周波数変動の検討
}

$\begin{array}{lllll}\text { 正員 本 } & \text { 間 } & \text { 环 也 } & \text { (筑波大) } \\ \text { 韭会員 仲 } & \text { 間 } & \text { 健 } & \text { (筑波大) } \\ \text { 正員 大 } & \text { 澤 } & \text { 靖 } & \text { 治 } & \text { (筑波大) }\end{array}$

\section{1. まえがき}

現在，我が国の離島の多くは，ディーゼル発電を用 いた電力系統によって電力僛給されているが, 燃料, 保守などのコストが高いために発電コストが高く、管 源の增設や更新契機として，太隄光発電が最も早く 実用的に導入される分野の一つ之菅えられている。沖 繣県の離島においては，笔力貯蔵システムとして蓄電 瑯を有する一芯独立した電源として太陽光発笔システ ムを構成し，日照不足時にディーゼル発電でバックア ップする方式で武験加行われている(1)。しかし，太陽 電池のコストが近年の技術開発によって低下しつつお るのに対して，蓄電池のコストは大幅に低下する見と おしがなく，太隄光発電システム全体に占める蓄電池 のコストの割合が梅対的に大きくなる倾向にある ${ }^{(3)}$ 。

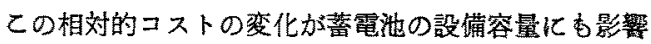
を及ぽすと考えられる。

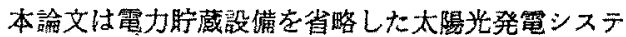
ムをディ一ゼル発電系统汇連系したときの運転特性を 明らかにする目的で, 太陽光発電の設䚛容量し趿作之 の関係，ならびに系統周波数変動特性について検討し たものである。まず，太陽光発電システムのモデル化 の手頟と運用力式について路述し，日射データおよさ 実際のディーゼル発雪系統の特性を用いた年間シミュ レーションによって，ディーゼル発電容量に対する太 踢光発電の比率之然料節減率の関係などを求める。亦

\footnotetext{
Studies on Optimum Capacity and Frequency Deviation of Photovoltaic Generation Interconnected to Diesel Generation Power System. By Takuya Homma, Member, Ken-ici Nakama, Nonmember \& Yastharu Ohsawa, Member (Institute of Engineering Mechanics, University of Tsukuba).

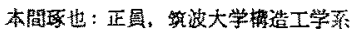

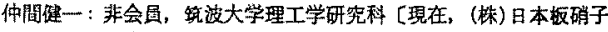
筑波研究所]

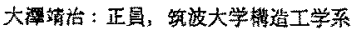

た，太陽エネルギーの有效利用の点加ら，太姐光発電 の最適容量について検討する。蓄暼池の省略により太 隄光発電システムは，発電時常にディーゼル発電系統 に並列されるととになるため，日射変動に起因する出 力変動が周波数変動を引き起とす恐れがある。この問 題に関してす，单純な例題系統によって檢詰する。

\section{2. 太陽光発電システムのモデル化と運転 方式}

年間シミュレーションによってディーゼル発笔系統 に拈りる太陽光発電システムの有效性, 最適容量を检 討するために，太陽光発電システムのモデル化と運用 方式の決定を行う必要がある。本章では，てれらにつ いて簡単に記述する。

〈2.1〉太隄归池アレイ 対象亡する太陽业発電 システムの構成图を图 1 に示す。太陽電池の $I-V$ 特 性は，周知の上うに次式で表すとよができる。

$$
\begin{aligned}
I= & I_{p}-I_{0}\left[\exp \left\{\frac{q}{n k T}\left(V+R_{s} I\right)-1\right\}\right] \\
& -\frac{V+R_{s} I}{R_{s h}} \ldots \ldots \ldots \ldots \ldots \ldots \ldots \ldots \ldots \ldots
\end{aligned}
$$

ただし， $I_{p}$ : 光電流 (A)， $I_{0}$ : ダイオード飽和 電流 (A)， $n$ : 新料によって決まる定数， $k$ : ボルッマン定数 $\left(=1.38 \times 10^{-23} \mathrm{~J} / \mathrm{K}\right), T:$ 絶 対温度 $(\mathrm{K}), q$ : 電子 1 個 電荷 $(=1.6 \times$

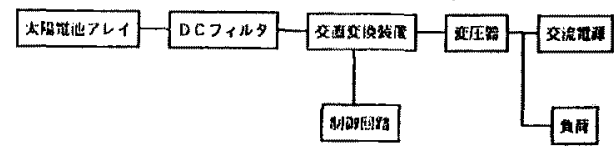

因 1 太陽光発電システムの構成目

Fig. 1. Block diagram of photovoltaic generation system. 
表 1 太隄電池の定数

Table 1. Constants of solar cell.

\begin{tabular}{l|l}
\hline$\kappa(=q / n k T)$ & 0.3882 \\
$I_{0}$ & $1.968 \mathrm{E}-6$ \\
$R_{s}$ & $0.7 \Omega$ \\
$R_{s h}$ & $1,750 \Omega$ \\
$I_{\delta}\left(1 \mathrm{~kW} / \mathrm{m}^{2}\right)$ & $5.35 \mathrm{~A}$ \\
$\beta$ & $3.956 \mathrm{E}-3$ \\
\hline
\end{tabular}

$\left.10^{-19} \mathrm{C}\right\rangle, R_{s}$ : 電極などの直列括抗 $(\Omega), R_{s h}$ :

$P N$ 接合欠陥などに上る分路抵抗 $(\Omega)$

また素子温度の変化によるパラメータの変化は, 短絡 電流 $I_{\mathrm{s}}$ が実用的な使用温度範囲内ではほとんど変化 しないので，付録（1）に示すような温度補正式で特性 曲線を補正できるものとする。

小規模な実験システムに用いた太隄電池アレイ（素 子温度 $28^{\circ} \mathrm{C}$, 日射量 $1 \mathrm{~kW} / \mathrm{m}^{2}$ の標準状態で開放電圧 $V_{o c}=20.2 \mathrm{~V}$, 短絡電流 $I_{s}=2.70 \mathrm{~A}$, 最大電力 $P_{m}=$ $40 \mathrm{~W}$ の太陧電池モジュールを直列に 2 枚，並列化 2 枚接続した 4 枚からなるアレイ) の諸定数を求歹と 表1のようになった。ただし，q/nkTをたとおいた。 太郿電池は容量によって特性が変化しないので，第 4 章のシミュレーションにおいては表 1 の特性を用い る。また，太陽光発電の容量 $S_{c}$ はディーゼル発電の 定格容量を基準にした次式の単位法で表すことにす る。

$$
S_{c}=\frac{\text { 標準状態での太陽電池アレイの最大出力 }}{\text { ディーゼル発電機の定格容量 }}
$$

〈2.2〉直交变換装置と軍転方式 $\mathrm{DC}$ フィルタ を含めたインバータの特性は，付録 (2)亿示す等価回 路によって近似することができる(4)。太隄電池の出力 を有効に利用するために，太陽電池アレイの最大出力 $P_{m}$ や太陽光発電システム全体の最大出力 $P_{s m}$ を追尾 する制御（それぞれ $P_{\text {max }}$ 追尾制御および $P_{s \text { max }}$ 追尾 制御と呼ぶことにする) が行われる。簡単なシステム ておいては，てのような制御を行わず一定のインバー 夕電生で運転されることあある。最適な一定運転電生 は, 設置点の年間気象データを用いたシミュレーショ ンを行うととによって决定できる。しかし，より簡便 な方法として, 日射量および気温の範囲を設定し，そ の籍囲内で $P_{s \text { max }}$ 追尾制御化対して出力低下が最守 小さくなるように，インバータ電圧 $V_{d}$ を決定するこ とができる(4)。

直交変換装置は大容量になるほど勃率が向上するの で，直交変換装置のシミュレーションモデルとして は，最む効率の低いモテルとして，@実験システムの インバータに電圧一定制御を行った場合, また最む効

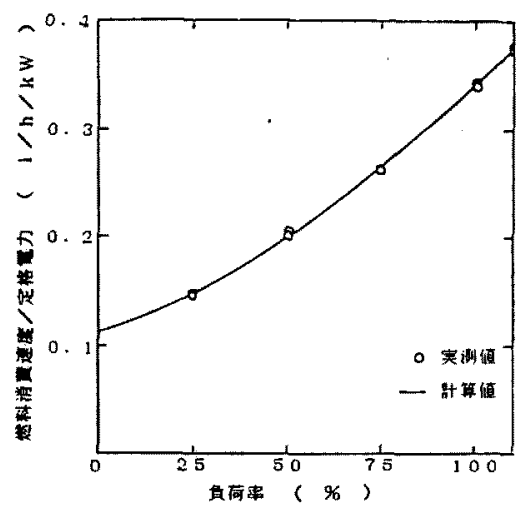

因 2 ディーゼル発電機の燃料消費率特性

Fig. 2. Fuel consumption rate of diesel generator.

率の高いモデルとして，®効率が 100\% の理想インバ 一夕を仮定し，乙れK $P_{s \max }$ 追尾制御を適用した場 合，の二種のモデルを考える。のモデルはシステム 効率 $100 \%$ であり，太晹光発電システムの限界性能を 与える。

\section{3. ディーゼル発電系統の特性}

〈3.1〉 ディーゼル発電機 ディーゼル発電機は, 離島で現実に使用されている2機の発電機の燃料消費 率の椡定データを用いて特性をモデル化する。2 機の 発電機（定格 $50 \mathrm{~kW}$ 之 $100 \mathrm{~kW}$ ）の負荷率に対する 燃料消頯率特性を园 2 亿示す。同図加ら，燃料消替率 $V_{o}(l / \mathrm{h})$ は, 火力発電機の場合之同様汇 ${ }^{(5)}$ 目荷率の二 次関数で近似できることが予想される。最小二乘近似 の結果, 図示のように次式で十分正確に近似できるこ とがわかる。

$$
V_{c} / P_{L N}=0.112+0.127 F_{R}+0.104 F_{R}^{2}
$$

ただし， $P_{L N}$ : ディーゼル発電機の定格容量 $(\mathrm{kW}), F_{R}$ : 負荷率

また，第 5 章で示すように，ディーゼル発電機の負 荷変動に対する追㮸性は比較的優れており，全負荷し ○断などの急激な变動に対して数秒で追従できる。従 って, 日射変動による太陽電池の出力変動に対しても 十分に追従できると考えられるので, 本節でのディー ゼル発電機のモデルは過渡特性は問題ないむのとし， 燃料消費摔は(3)式で表されるむのとする。

〈3.2〉負荷バターンと気象データ 負荷バター ンについては，九州の離島における実例を用いた。乙 のデータは月別，時間どとの平均值として与えられて 
おり，年負荷率 62\% である。一般の日目荷曲線と比 較すると日中に比へて夜間の負荷が大きくなってお り、眝蔵設備なしの太晹光発電によっては不利な負荷 パターンとなっている。気象データには，離慰の条件 に近いものとして高知の一年間の日射量と符温の值を 用いた。また，システム全体の運用についで，昼 間, 太显光発電システムの出力が負荷を上回ったとき 余剩笔力を生じるが，こ扎は漣れ制御角 $\alpha$ を調整す ることにより吸取し，負荷との整合を困る。太樭光発 電の出力が不足しているときおよび夜間は，ディーゼ ル登電加ら供給するあのとしてシミュレーションを行 5。

\section{4. 連系系統のシミュレーション䊅果}

モデル(A)（実験システム）およびモデル(B)（理想シ ステム)を用いたシミニレーションの結果をそれぞれ 图 3，图4 亿示す。ディ一ザル発電機と太陽炎発電の

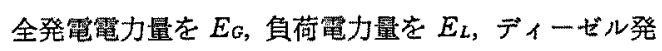

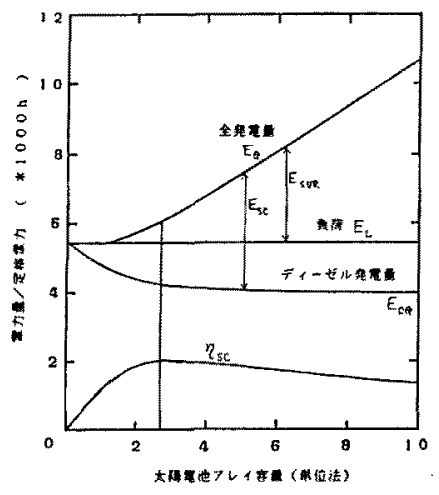

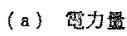

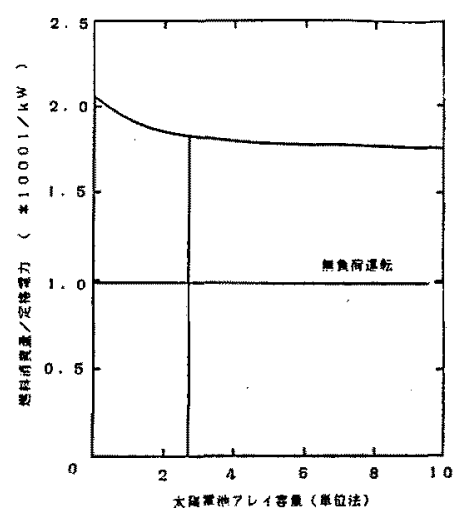

(b) 燃料消费量

区 3 シミュレーション結果 (モデル (d)

Fig. 3. Results of simulation by model (A).
電機の発電電力量を $E_{D C}$, 太陽光発電システムの発 電電力量を $E_{S C}$, 余剩党力量を $E_{S U R}$ とすれば $E_{s c}$, ESUR は次式で表される。

$$
\left.\begin{array}{l}
E_{S C}=E_{G}-E_{D G} \\
E_{S U R}=E_{G}-E_{L}
\end{array}\right\}
$$

太陽光発電の容量 SC の增大に伴い，ESC が增加す るために $E_{D C}$ は滅少する。しかし，ある限度以上に $S C$ を增加してお， $E_{S C}$ の增加量の大部伃が $E_{S U R}$ 上 なり，EDGはによど減少しなくなる。EDGの収束值 はインバータの数率および連軽方式に依存することが わかる。

太陽光発電を補助的に使用する場合には， $E_{S U R}=0$, つまり全発電量加負荷に等しい筑舟内で $S_{c}$ を設定 すればよい。モデル@では $S_{c}<1.1$ ，モデル(B)で $S_{C}<0.8$ である。太陽光発雪システムの上り稹極的な 利用を検詒するために，次式のような評価指標を導入 する。

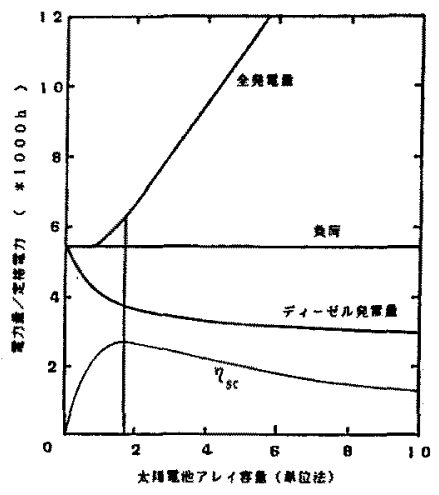

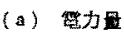

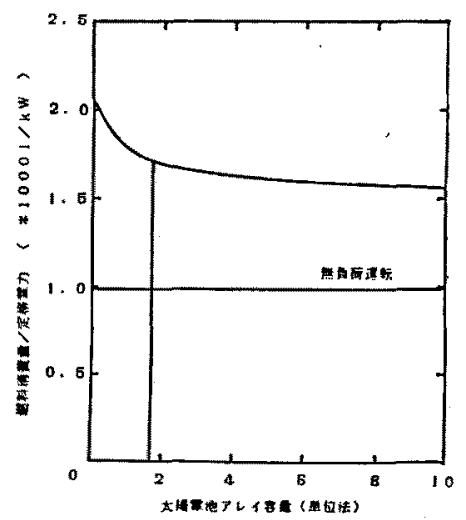

(b) 燃料消震用

圀 4 シミュレーション結果 (モデル (B)

Fig. 4. Results of simulation by model (B). 


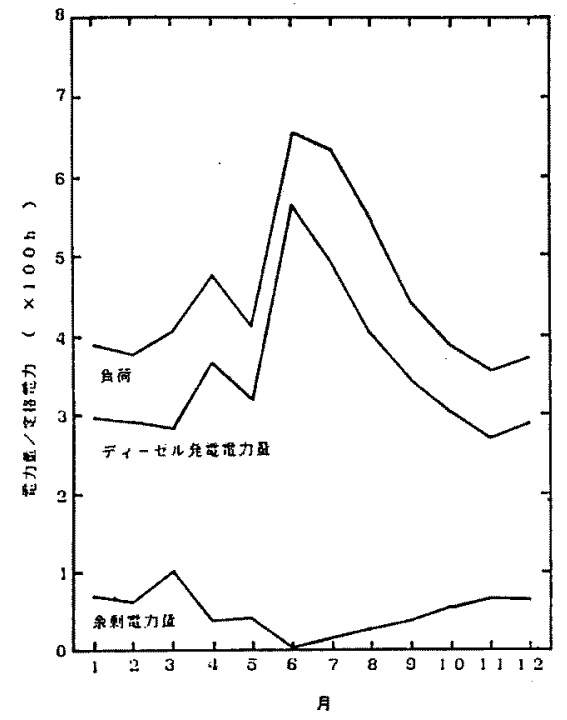

图 5 月別発電特性 $\left(S_{C}=2.7\right.$, モデル (A))

Fig. 5. Variation of monthly output by model (A) $(S c=2.7)$.

$$
\begin{aligned}
& \text { 太陽光有効発電率 }(\eta S C) \\
& =\left(E_{S C}-E_{S U R}\right) / E_{G} \\
& =\left(E_{S C}-E_{S U R}\right) /\left(E_{S C}+E_{D G}\right)
\end{aligned}
$$

$\eta s c$ は太陽光発電システムから実際負荷化供給さ れた電力の全発電電力量（余鄱分 $E_{S U R}$ 毛含む）に対 する比を表す。モデル@の場合， $S c=2.7$ で $\eta_{s c} は$ 最大となり，とのときディーゼル発電機の発電電力の 減少量（定格で規格化） $\Delta E_{D G}$ は $1,224 \mathrm{~h}$ であり，減 少率は $22.4 \%$ である゙。モデルßではインバータの効 率が高いため, $S_{C}=1.7$ で $\eta s c か ゙$ 最大となり，とのと き $\Delta E_{D G}=1,707 \mathrm{~h}$, 減少率は $31.2 \%$ である。ディー ゼル発電機の败料消䩀量 VDG は，図 $3(\mathrm{~b})$ ，図 4 （b）加らかるように，無負荷運転時においても燃料 を消費するため，電力量の減少と比較して節減できる 割合は小さくなり，モデル®の場合， $S c=2.7$ で然料 節減量 $\Delta V D G$ は年間で $250.8 \mathrm{l} / \mathrm{kW}$ ，節減率は 12.2 $\%$ ，モデル(B)では， $S_{C}=1.7$ のとき $\Delta V_{D G}=356.5$ l $\mathrm{kW}$ ，節減率 $17.2 \%$ である。

モデル®で $S_{C}=2.7$ の場合の月別発電特性を図 5 飞示す。同図加らかるように，冬期に余剩電力が增 加している。乙れは冬期の尽間負荷が小さいととと， 気温が低いために太陽電池の変換効率が高くなるため に太陽光発電の出力が增加することによる。6月は梅 雨のために日射量が少なく，余剩電力はほとんど出な w。

돌 学論 D, 108 巻 2 号, 昭 63

\section{5. 周波数変動の検討}

太陽光発電の上うな変動性の電源が， ある比率以上 電力系統に連系されると周波数変動，電圧变動などが 問題となる可能性がある。これらのうち，本章では前 章で分析したような電力貯蔵設備をもたない太陽光発 電システムが，ディーゼル発電系統化連系された場合 について，雲の移動に上る日射変動時の太陽光発電の 出力変化が系統周波数に及隹す影響を単純なモデル系 統を用いて検剷する。

〈5.1〉系統のモテル化 図6に示すような集中 負荷に，送電線を介して電力を供給している $150 \mathrm{~kW}$ 定格のディーゼル発電系統を考える。発電機は過渡リ アクタンスに直列接続された一定電圧モデルで表現す る。発電機定数は表 2 亿示す。調速機の特性は実際の ディーゼル発電機の負荷遮断試験時の周波数変動より 伝達関数の形と定数の值を求めた。

$$
\Delta P_{m}=\frac{-K_{q}(1+s)}{\left(1+T_{a} s\right)\left(1+T_{q} s\right)} \Delta \omega
$$

ただし， $\Delta P_{m}$ : 発電機への機械入力の変化,

$\Delta \omega$ : 発電機の回転子角速度の変化（周波数

の変化), $K_{a}=41.7, T_{a}=8.3 \mathrm{~s}, T_{a}=0.025 \mathrm{~s}$ とのとき，系統の方程式は線形微分方程式となり

$$
\begin{aligned}
& {\left[\begin{array}{c}
\Delta \dot{\omega} \\
\Delta \dot{P}_{m} \\
\Delta \dot{P}_{a}
\end{array}\right]=\left[\begin{array}{c}
D / M \\
0 \\
-(1-D / M) K_{q} /\left(T_{a} T_{0}\right)
\end{array} *\right.} \\
& \left.* \begin{array}{cc}
1 / M & 0 \\
0 & 1 \\
-\left(K_{q} / M+1\right) /\left(T_{a} T_{q}\right) & -1 / T_{a}-1 / T_{a}
\end{array}\right] \\
& \times\left[\begin{array}{c}
\Delta \omega \\
\Delta P_{m} \\
\Delta P_{a}
\end{array}\right]+\left[\begin{array}{c}
1 / M \\
0 \\
-K_{\theta} /\left(M T_{a} T_{\sigma}\right)
\end{array}\right] \Delta P_{s c}
\end{aligned}
$$

\begin{tabular}{|c|c|}
\hline 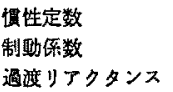 & $\begin{array}{l}M=5 \mathrm{~s} \\
D=0 \mathrm{pu} \\
x_{d^{\prime}}=0.3 \mathrm{pu}\end{array}$ \\
\hline
\end{tabular}

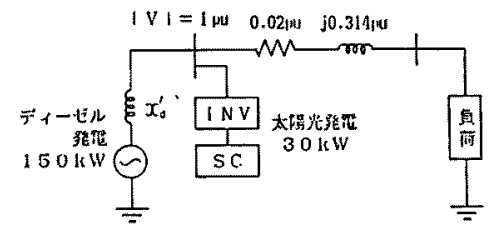

困 6 系統モデル

Fig. 6. Model power system.

表 2 発電機の定数

Table 2. Constants of generator. 


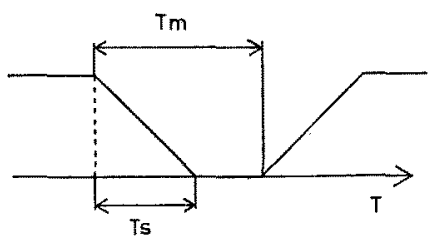

図 7 太陽電池出力変化

Fig. 7. Time variation of photovoltaic output.

で与えられる(導出仙付録 ( 3 )参照)。

太陽光発電については太陽電池パネルの所要面皘を $20 \mathrm{~m}^{2} / \mathrm{kW}$ とし， $25 \mathrm{~m}$ 四方の用地化設置していると 仮定する。雲の通過化よって太晹電池の出力が直線的 に減少または增加する屯のとし，雲の速度を 5〜 $\mathrm{m} / \mathrm{s}$ とすると，日射が減少し始めてから太晹電池が完 全汇雲侸われるまでの時間 $T s$ は $5 \sim 0 \mathrm{~s}$ となる。 時間 $T$ の原点を日射娍少開始時にとり，日射が再び 增加する時間を $T_{m}$ として，図 7 のように太陽光発雪 出力の変動をモデル化し

ケース 1 雲の面積が十分大きく，一度影になる

と当分睛れない $\left(T_{m} \rightarrow \infty\right)$

ケース 2 雲の進行方向の幅が太晹電池アレイの

幅 $(25 \mathrm{~m})$ 海等しい $\left(T_{s}=T_{m}\right)$

ケース 3 雲の幅が太陽電池アレイの幅より小さ

いか，ある程度大きい $\left(T_{s} \neq T_{m}<\infty\right)$

の三つの場合について計算を行った。

〈5.2〉計算結果と考察 ケース 1 の結果を $T$ s をパラメータとして図8 8 亿示す。Ts が小さく，出力 変化速度が大きい恬ど周波数の低下む大きく，出力変 動が終了してから一定周波数化安定するまでの時間も 長くかかることがわかる。定常偏差はゲイン K。を大 きくすることによって減らすことができるが，実際の

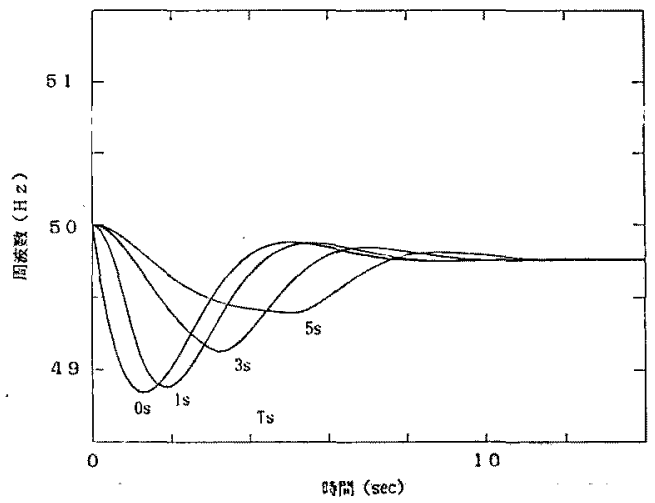

因 8 ケース1の周波数変動

Fig. 8. Frequency change in case 1.

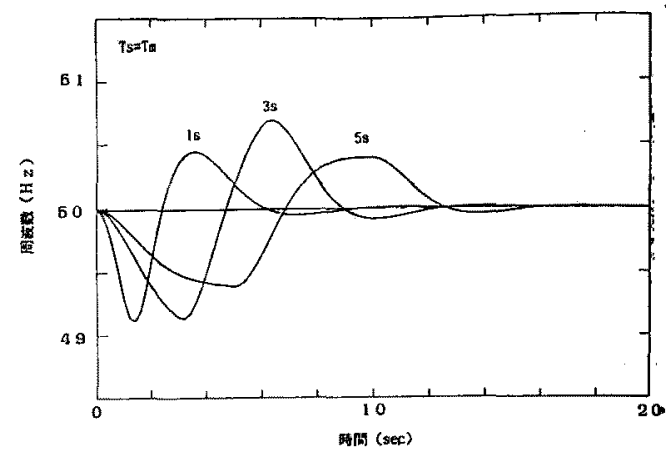

図 9 ケース 2 の周波数変動

Fig. 9. Frequency change in case 2 .

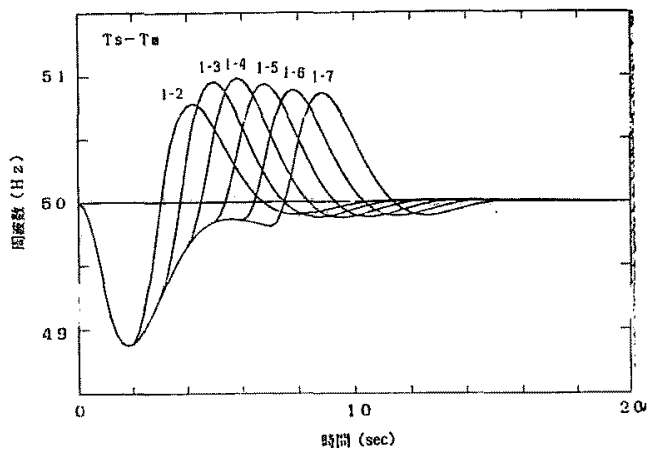

図 10 ケース 3 の周波数変動 $\left(T_{s}=1 \mathrm{~s}\right)$

Fig. 10. Frequency change in case $3\left(T_{s}=1 \mathrm{~s}\right)$.

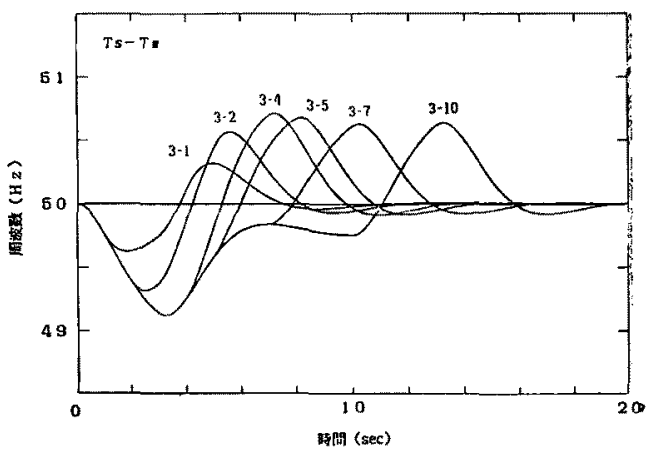

図 11 ケース 3 の周波数変動 $\left(T_{s}=3 \mathrm{~s}\right)$

Fig. 11. Frequency change in case $3\left(T_{s}=3 \mathrm{~s}\right)$.

調速機ではこの程度の定常偏差が生じる。

ケース 2 の結果を $T_{s}\left(=T_{m}\right)$ をパラメータとして 示す之図9の上うになる。 $T_{s}=T_{m}$ であるので，出力 が0となると同時に增加し始めるため，周波数低下仗 ケース1よりあ小さくなる。

$T_{s}=1 \mathrm{~s}$ および $T_{s}=3 \mathrm{~s}$ としたときのケース 3 の結 果を図 10，図 11 にそれぞれ示す。 $T_{m}$ が大きくなる 
ほど，出力减少による周波数低下と出力增加による周 波数上昇の間の関連が小さくなり， $T_{\mathrm{m}}=4 \mathrm{~s}$ のときに 最屯周波数上昇が大きくなる。との系の固有值を計算 すると固有振動数が $0.13 \mathrm{~Hz}$ (周期 $7.7 \mathrm{~s}$ ) であるの で, $T_{m}$ が固有周期の半分のときに共振条件に近くな り，周波数变動の幅が最大になると言える。

以上，いずれのケースについても，太隄光発電がブ ィーゼル発電の $20 \%$ の容量のときには，周波数変動 は最大 $1 \mathrm{~Hz}$ 程度であることがわかる。周波数計算の (7)式仙線形であるので，100\% 太陽光発電加ら供給 されている場合でも $5 \mathrm{~Hz}$ 程度の周波数変動で収まる というととであり，てれはディーゼル発電にとって許 容範囲内である。

\section{6.あとがき}

文戴(1)，(2)の試験設喵は年平均 $103 \mathrm{kWh} /$ 日の 負荷に対して, 出力 $50 \mathrm{kWP}$ の太陽電池厂レイ乙貯蔵 容量 $300 \mathrm{kWh}$ の蓄電池を使用するものである。との 設備の設計の詳細は明らかではないが, 太陽電池のコ ストが下がれば当然設計も異なったもの，つまり詝蔵 容量のより小さいシステムになると考えられる。本諭 文では蓞電池なしの場合の太陽光発電の容冒とディー ゼル発電電力および燃料消費の節的量の関係化ついて 分析した。現実には，ディーゼル発電の蜘料費，太晹 電池のコスト，蓄暼池のコストと寿命などを考虑した 最適なシステム設計が必要であると思われる。

また, 日射変動に伴う太陽光発電の出力変化加系統 周波数に及活す影響について計算した結果，日射の变 化が系統の固有振動数に近い周波数の周期的なすので ない限り，問題ないととがわかった。電壬変動につい ては今回検討を行わなかったか，乙れについて分析 する必要がある。

終りに，資料を提供していただいた電子技術総合研 究所怙よび九州電力(株)の関係各位に感謝の意を表し ます。実験拈よび数值計算に協力していただいた大学 院生 (当時) 阿部精順，近藤 敬の雨氏に感謝します。 (昭和 62 年 6 月 18 日受付, 同 62 年 9 月 30 日再受付)

\section{文献}

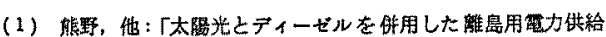

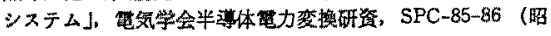
60-11)

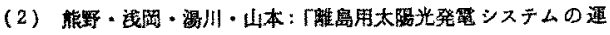
枟研究], 同上, SPC-86-75 (昭 61-9)

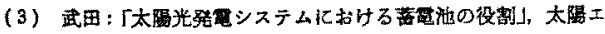
ホルギー，10，15 (昭 59-6)

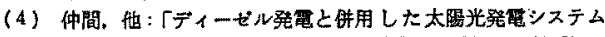

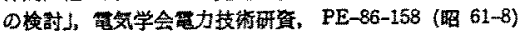

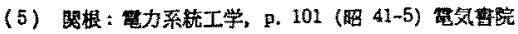

学踚 D, 108 巻 2 号, 昭 63

\section{付 録}

（1）太陽電池の $I-V$ 特性式の温度補正

$$
\left.\begin{array}{l}
I_{\mathrm{NEW}}=I_{\mathrm{REF}} \\
V_{\mathrm{NEW}}=V_{\mathrm{REF}}\left\{1+\beta\left(T_{\mathrm{REF}}-T_{\mathrm{NEW}}\right)\right\}
\end{array}\right\}
$$

ただし， $T_{\text {REF }}$ : 基準素子温度 $(\mathrm{K}) ， T_{\mathrm{NEW}}$ : 実際の素子温度 $(\mathrm{K}), I_{\mathrm{REF}}, I_{\mathrm{NEW}}$ : 素子温度 がそれぞれ $T_{\mathrm{REF}}, T_{\mathrm{NEW}}$ のときの電流 (A)， $V_{\mathrm{REF}}, V_{\mathrm{NEW}}$ : 素子温度がそれそれ $T_{\mathrm{REF}}$, $T_{\mathrm{NEW}}$ の之きの電圧 $(\mathrm{V}), \beta$ : 補正係数

（2）インバー夕の等価回路表現 インバータは 内部炕プロッキングダイオードやサイリスタなどの非 線形素子を含むが，乙れらを線形近似すると太陽電池 アレイに対するインバータの直流側等価回路は付図 1 に示すように，インバー夕直流側電圧の真流成分 $V_{d}$ ， 電生降下 $V_{i}$ ，内部抵抗 $R_{i}$ によって表現できる。実験 システムのインバータの $I-V$ 特性の測定結果から決 定したパラメータの值は $R_{i}=0.81 \Omega, V_{i}=2.40 \mathrm{~V}$ で あった。また、インバータの損失を $R i, V_{i}$ による損 失已直交変換似上る枟流挰失とに分離して考元，後者 を遅れ制御角 $\alpha$ の值によらず一定（実験システムで は $11.2 \mathrm{~W})$ としてインバータの勃率を計算すると付 因2の上うになる。 $\alpha$ の最大值（約 $168^{\circ}$ ) において最 大効率 $73 \%$ が得られる。

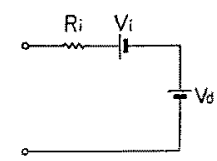

付図 1 試作インバータの直流側等価回路 app. Fig. 1. Equivalent circuit of DC side of experimental inverter.

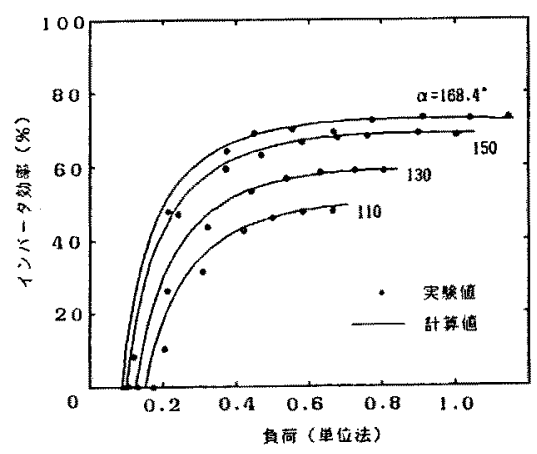

付图 2 インバータの効率 app. Fig. 2. Efficiency of inverter. 
（3）系統方式 (7) の導出発電機回転子の回 転の方程式は発電機への機械入力を $P_{m}$, 太陽光発電 の出力を $P_{s c}$ ，負荷の電力を $P_{L}$ とすると

$$
M \cdot d \Delta \omega / d t+D \Delta \omega=P_{m}+P_{s c}-P_{L}
$$

変分をとり， $d / d t$ を $s$ で表すと

$$
s \Delta \omega=-(D / M) \Delta \omega+\Delta P_{m} / M+\Delta P_{s c} / M
$$

また，調速機の伝達関数式 (6)より

$$
\begin{aligned}
& \Delta P_{m}+\left(T_{a}+T_{\vartheta}\right) s \Delta P_{m}+T_{a} T_{\vartheta} s^{2} \Delta P_{m} \\
& \quad=-K_{q}(1+s) \Delta \omega \ldots \ldots \ldots \ldots \ldots \ldots \ldots \text { (付 }
\end{aligned}
$$

$s \Delta P_{m}$ を $\Delta P_{a}$ において(付 3 )式を代入すると

$$
\begin{aligned}
s \Delta P_{a}= & -\left(1-\frac{D}{M}\right) \frac{K_{g}}{T_{a} T_{a}} \Delta \omega \\
& -\left(\frac{K_{g}}{M}+1\right) \frac{1}{T_{a} T_{g}} \Delta P_{m} \\
& -\left(\frac{1}{T_{a}}+\frac{1}{T_{q}}\right) \Delta P_{a}-\frac{K_{q}}{M} \frac{1}{T_{a} T_{g}} \Delta P_{s c}
\end{aligned}
$$

（付 3）（付 4) 式格よび $s \Delta P_{m}=\Delta P_{a}$ よb，(7)式之 なる。 